\title{
Convention Theory in the Anglophone Agro-food Literature Past, Present and Future
}

\author{
Ponte, Stefano
}

Document Version

Accepted author manuscript

Published in:

Journal of Rural Studies

DOI:

10.1016/j.jrurstud.2015.12.019

Publication date:

2016

\section{License \\ CC BY-NC-ND}

Citation for published version (APA):

Ponte, S. (2016). Convention Theory in the Anglophone Agro-food Literature: Past, Present and Future. Journal of Rural Studies, 44(4), 12-23. https://doi.org/10.1016/j.jrurstud.2015.12.019

Link to publication in CBS Research Portal

\section{General rights}

Copyright and moral rights for the publications made accessible in the public portal are retained by the authors and/or other copyright owners and it is a condition of accessing publications that users recognise and abide by the legal requirements associated with these rights.

Take down policy

If you believe that this document breaches copyright please contact us (research.lib@cbs.dk) providing details, and we will remove access to the work immediately and investigate your claim. 


\title{
Convention Theory in the Anglophone Agro-Food Literature: Past, Present and Future Stefano Ponte
}

\author{
Review (Post print version)
}

\author{
This article was originally published in Journal of Rural Studies, Vol 44, \\ Nr. 4, २016, pp. 12-23. \\ First published online 11 January २०16. \\ 001: 10.1016/j.jrurstud.2015.12.019
}

Uploaded to Research@CBS: February २०16

(1) 2016. This manuscript version is made available under the CC-BY-NC-ND 4.0 license http://creativecommons.org/licenses/by-nc-nd/4.0/ 


\title{
Convention theory in the Anglophone agro-food literature: Past, present and future
}

\author{
Accepted for publication to Journal of Rural Studies \\ Stefano Ponte, \\ Professor of International Political Economy \\ Dept. of Business and Politics \\ Director, CBS Sustainability Platform \\ Copenhagen Business School \\ Steen Blichers Vej 22 \\ 2000 Frederiksberg, Denmark \\ sp.dbp@cbs.dk
}

\section{Introduction}

In the past two decades, convention theory $(\mathrm{CT})^{1}$ has influenced various branches of agrofood studies, providing analytical guidance and theoretical insight for examining alternative food networks, coordination and governance of agro-food value chains, and the so-called 'quality turn' in food production and consumption. This influence has been part of a wider trend in the Anglophone social sciences more generally (Wilkinson, 1997; Raikes et al., 2000; Biggart and Beamish, 2003; Stark, 2009; Barnett, 2014; du Gay and Morgan, 2013) and took place especially since the two main reference books On Justification (Boltanski and Thévenot, (1991)[2006]) and The New Spirit of Capitalism (Boltanski and Chiapello; (1999)[2005]) were translated into English in the mid-2000s.

CT has attracted attention especially in sociology, but has also informed key debates in geography/regional studies and in (international) political economy. In sociology, the propagation of CT reflects 'a broad return of a concern with thinking of the normative dimensions of social life in ordinary, routine, practical ways' (Barnett, 2014: 157), not only in relation to solving coordination problems in situations of uncertainty (a central tenet of CT), but also in examining the creative role of 'dissonance' between competing evaluative principles in situated contexts (Stark, 2011). In geography, CT has been applied in discussions on normativity and ethics, and on how to locate individual action in the context of social practices (Barnett, 2014). This has raised calls for an analysis of plural geographies of worth through the examination of the coordination of actions in time and space that operates 'through the negotiation between multiple practices of evaluation, justification and accountability' (Ibid.: 157).

A distinct application of CT has happened in economic geography and regional studies, where conventions have been used to characterize a combination of different market orientations and production processes, or 'worlds of production', that have specific territorial elements (Salais and Storper, 1992; Storper and Salais, 1997). Finally, in (international) political economy, CT has been used to integrate normative elements into structural analyses of power and unequal distribution of value in economic activity - to understand, for example, the governance of global value chains, the alignment of managerial practices to expected models of 'best practice' (Daviron and Ponte, 2005; Gibbon and Ponte, 2005), and the management of farm labour (Riisgaard and Gibbon, 2014; Gibbon and Riisgaard, 2014).

\footnotetext{
${ }^{1}$ By 'convention theory' in this article, I mean work related to justification, orders of worth and (quality) conventions developed originally by Luc Boltanski and Laurent Thévenot. This is a sub-set of a broader literature, collectively known as 'French pragmatic sociology' that examines (e)valuation in action that raises critique (Boltanski, (2009[2011]) and is more widely involved in a plurality of 'regimes of engagement' (Thévenot, 2006). The latter is covered elsewhere (Author, 2016).
} 
In this article, I review the existing Anglophone literature on agro-food studies that has mobilized CT in its theoretical, analytical and/or empirical work. Given the space constraints, the two foci here are on: (1) how CT has helped explain different modes of organization and coordination of agro-food operations in different places; and (2) how it has provided new venues of approaching quality in view of understanding how exchange of agro-food products takes place and with what social and power dynamics. While the ethical and normative content of 'quality' is considered in this review, less attention will be placed on the impact CT has had indirectly on discussions of ethics and normativity in the broader agro-food literature (Barrientos and Dolan, 2006; Goodman and Sage, 2014). An analysis of the specific genesis of CT in the French social sciences is briefly included in this article, but does not extend into considerations of what it means for the specific pattern of diffusion it has taken in the Anglophone agro-food literature (for these considerations, see Author, 2016).

Under the banner 'Anglophone literature', I consider work published in English by scholars who are not institutionally based in France or who have not been trained there. Under the 'agro-food studies' category, I include literature on the production, processing, trade, distribution, cooking, use and re-use/re-cycle of agricultural, fishery and forestry products for food, feed and industrial purposes, and their environmental interactions. The resulting list of 51 articles, books and book chapters has been developed through searches in Google Scholar and Scopus on 'convention(s)', 'worth', 'convention theory', and 'pragmatic sociology', then filtered to match whether they apply to the agro-food sector and qualify as 'Anglophone'. This procedure was also complemented with 'snowball' sampling, the looking up of relevant references from articles already in the list. Some articles have been included in the list because they provide relevant reviews of theoretical and analytical debates, even though they are not exclusively referring to agro-food studies (see details in section 3.1).

In the next section, I provide a brief discussion of the main features of CT as emerging from the Francophone literature. In the following section, I review the Anglophone literature that applies CT to agro-food studies. I highlight its main characteristics, and discuss the two main (and sometimes overlapping) strands that have emerged: a first following the 'worlds of production' approach; and a second focused on 'orders of worth' and quality conventions. In the conclusion section, I highlight broad trajectories, the significance of new developments, the current limitations of the Anglophone literature, and suggest some future directions for research.

\section{Convention theory}

In convention theory, ${ }^{2}$ conventions are defined as a broad group of mutual expectations that include - but are not limited to - institutions. While institutions are collective and intentional objects that are set up for the purpose of implementing an intention, conventions may also arise from a shared set of regularities that are unintentional. For CT, rules are not decided prior to action, but emerge in the process of actions aimed at solving problems of coordination. Conventions are then mechanisms of clarification that are themselves open to challenge (Wilkinson, 1997; Raikes et al., 2000). Conventions are not fixed in time and space: they include mechanisms of clarification that are themselves open to challenge. They are both guides for action and collective systems to legitimise those actions that can be submitted to testing and discussion, leading to compromises and possibly defeat (Boltanski and Thévenot,

\footnotetext{
2 In some of the literature on conventions, a distinction is made between 'convention economics' (see edited collections by Batifouier, 2001, $3^{\text {rd }}$ part; Orléan, 2004; Favereau and Lazega, 2002; and parts of EymardDuvernay, 2006a, 2006b) and 'convention theory' as such. Given that the Anglophone agro-food literature has applied almost exclusively the latter, in this article I do not review the former.
} 
1991[2006]; Ponte and Gibbon, 2005; Wilkinson, 1997). Thus, we can see conventions as systems of reciprocal expectations about the behavior of others (Salais, 1989) or, more precisely as 'shared templates for interpreting situations and planning courses of action in mutually comprehensive ways that involve social accountability, ... provid[ing] a basis for judging the appropriateness of action by self and others' (Biggart and Beamish, 2003: 444).

In On justification, Boltanski and Thévenot (1991[2006]) argue that action, when devised to cope with criticism and justification, is made more legitimate by relying on forms of valuation that refer to particular views of the common good. To deal with suspicion and critique, justifications need to rely on reality tests. These tests involve both people and objects and are related to modes of coordination that are based on six historically-based 'worlds' ${ }^{3}$ These worlds are organized around different principles of qualification (see summary in Table 1):

- In the inspired world, the common principle is spiritual or creative enhancement through passion. The objects and arrangements that equip worth stem from a mind and a body that are prepared for the break of creation. The test, which eludes measure, is an adventurous lived experience or is attached to a unique set of practices that can not certified through formal audits. Firms draw on the concept of creativity.

- The domestic world is related to the family and the common principle of traditional benevolence, care provision and trustworthiness; it extends the chains of hierarchical and personal dependency through generations. The test, is based on oral evidence (firms draw on the concept of loyalty).

- In the world of fame, the common principle is celebrity or renown in public opinion. A higher state of worthiness is reached when one becomes famous and visible. Qualified objects are recognition signs, and the test is to be known and visible. Firms use the concept of reputation.

- In the civic world, the common principle is collective and anonymous solidarity and the state of worthiness depends on one's public agency as representing the collective. The subjects in this world are delegates, representatives, and members. The objects support the representation of the collective - e.g. slogans, policies, rules and legal forms. The test is reached through meetings and assemblies, which produce representation. Firms refer to the idea of responsibility.

- In the market world, the common principle is market competition. The test is constructed via deal-making, and evidence is provided by the price of market goods and services, including labour. Firms organize themselves around the concept of competitiveness.

- In the industrial world, the common principle is efficiency. The test is based on technical efficiency and scalability, proper functionality. Evidence for testing is technical and objectively measurable. Firms evoke the concept of productivity.

\section{TABLE 1 here}

In one of the first developments, CT extended the notion of 'social coding' to 'investing in forms' (laws, rules, instructions), which constitute assets and foster 'the regulation of established relations' (Thévenot, 1983, 1984, 2015b). This was related to Eymard-Duvernay's research on models of firms and production, which linked the 'qualification' of labor to the quality of products and commodities (Eymard-Duvernay, 1986; Eymard-Duvernay and

\footnotetext{
${ }^{3}$ More specifically, according to Boltanski and Thévenot (2006: 140-144) different worlds are characterized by variation along a number of elements: a higher common principle; states of worthiness and relations of worth; characterizations of common dignity; lists of 'worthy' subjects, objects and arrangements; investment forms to achieve worthiness; 'natural' relations among beings; harmonious figures of the natural order; model tests; modes of expression of judgment; forms of expression of judgment; and states of deficiency that may lead to decline.
} 
Thévenot, 1986; see also Salais and Thévenot, 1986). During the very first years of this development of CT, empirical research dealt with various production processes, from the making of cheese to the provision of credit.

In further work, convention theorists and other scholars developed other categories, such as the 'green world' (Latour, 1998; Thévenot et al., 2000; Blok, 2013), the 'information world' (Thévenot, 1997) and the 'network world' (also known as 'project-oriented' or 'connectionist') (Boltanski and Chiapello, 1999; see also Thévenot, 2002). While the proliferation of categories may be problematic, CT does not place a hierarchical value to these worlds, nor does it portray any of them as historical inevitabilities. In contrast to other political economy approaches in agro-food studies, such as the food regimes and commodity system literatures (Friedmann 1987; Friedmann and McMichael, 1989; Friedland, 1994; McMichael, 1994; Pritchard, 1996), interests in CT are neither permanent, nor are they linked ex-ante to specific social groups. Furthermore, at any particular time and locality, there may be multiple justifications of action operating at the same time. Finally, although there is an internal coherence in each world, there are also qualifications that 'bridge' different worlds. This does not mean that CT is devoid of power considerations or that it is purely 'representational'. CT highlights that different conventions underpin different forms of organization, coordination and exchange. Different conventions entail specific cognitive barriers and asymmetries in power relations among participants. Thus in order to either attempt to change the status quo or at least extract more 'value' from a transaction or an organizational form, disadvantaged actors in different situations need to apply different leverage points.

CT indicates that - over time - markets come to embody a succession of different criteria under which goods become qualified for trade, and according to which trade is subsequently managed. Along with the 'quality turn' and alternative food networks literature (Goodman and Watts, 1997; Goodman 2004; Goodman et al, 2014), one of the main tenets of CT is the observation that until the early 1970s, quantification was the main criteria for arbitrating exchange of relatively homogeneous products, while the current economic dynamic is based on 'an obsession with quality'. In CT, markets are said to function on the basis of principles of product qualification. At the same time, quality is a key organizational concept for understanding the basis of emerging competitive strategies (Allaire and Boyer, 1995; Valceschini and Nicholas, 1995).

These lines of thinking were developed further in three directions: (1) Salais and Storper (1992; see also Storper and Salais 1997) developed a typology of 'worlds of production' as a combination of technologies and markets, product qualities, and practices of resource use; (2) Eymard-Duvernay (1989) formulated a framework linking quality conventions to forms of coordination; and (3) Thévenot (1995) and Boltanski and Chappello (1999) showed how, in different historical periods, different combinations of predominant conventions occur. The first two directions seek to formulate forms of organization, coordination and exchange specific to the nature of the product that is exchanged, and the means of justifying its quality claims. The third is focused on how these change over time.

The first direction was developed by Salais and Storper (1992), who formulated four 'worlds of production' distinguished on the basis of two dimensions that can take two values: the first dimension is related to the available supply of technology, information and skills at the production level, and whether these are restricted to a community of specialists or not (yielding specialized or standardized products respectively); the second dimension is related to whether demand is anonymous and uniform or not (yielding demand for generic or dedicated products respectively). The four possible combinations lead to a classification of 'worlds of production' as follows: (1) Industrial World (production of standardized-generic products); (2) Network Market World (standardized-dedicated); (3) Marshallian Market 
World (specialized-dedicated); and (4) World of Innovation (specialized-generic) (slightly different labels are used in Storper and Salais, 1997).

Although each world has its specific characteristics, Salais and Storper (1992) also point out that there are frictions, failures and compromises between worlds. They argue that each world of production involves coordination between agents that is shaped by conventions and explore two kinds of conventions: (1) quality conventions that 'establish the boundaries of competition in a world by defining the relative economic values of qualitatively distinct factors of production' (Ibid.:179-180); and (2) conventions of flexibility that define practices of resource deployment, noting that these shape the difference between specialized and standardized products. This approach was employed most explicitly in the 'worlds of food' literature (and more recent literature on innovation) and is thus one of the clearest examples of CT's role in influencing agro-food studies more generally.

The second direction was developed by Eymard-Duvernay (1989; see also Sylvander, 1995; Thévenot, 1995), who formulated a typology of quality conventions that underpin different forms of coordination. The main point of departure for his typology is that price is the main management form of a particular market only if there is no uncertainty about quality. If this is the case, differences in price are equated with quality. This characterizes what CT calls coordination based on 'market' conventions (see Table 1). Eymard-Duvernay argues that when price alone cannot evaluate quality, economic actors adopt other quality conventions to solve problems of coordination. Domestic conventions help solve uncertainty about quality through trust (long-term relationships between actors or use of private brands which publicize the quality reputation of products). In this case, the definition of quality is resolved internally, and the identity of a product is guaranteed or institutionalized in the repetition of history by its region or country of origin or by a brand-name. Industrial conventions help solving uncertainty about quality through the actions of an external party, which determines common norms or standards and enforces them via instrument-based testing, inspection and certification. To these, Thévenot (1995) added three other quality conventions: a civic convention, where there is collective commitment to welfare, and the quality of a product is related to its impact upon society or the environment (see also Sylvander, 1995); an inspired convention, where the personality of one of the actors in the exchange, his/her genius, intuition, creativity, and/or vision substitutes for other means of assessing quality; and a convention of fame (also referred to as opinion convention), where uncertainty about quality is resolved through the convergence of widespread recognition which might involve the opinion of a reputable actor that is external to the exchange (see also Ponte, 2009).

Each of these quality conventions implies asymmetries of information that benefit certain groups of participants over others in different ways, with different configurations of winners and losers. And different forms may exist side by side at the same time, even for the same product. According to Allaire and Boyer (1995), these conventions and related forms of coordination may exist in a state of tension where one is trying to either resist or encroach on other modes, leading to new compromises. But when different criteria come to challenge the very nature of the process of qualification, a change in the dominant form (or combination of forms) of coordination may occur. This approach was most clearly adopted in agro-food studies by the literature on governance in global value chains, and particularly that examining 'normalization' processes (see below). But the rich debate on ethics was also influenced by the quality convention framework, especially in relation to whether organics and fair trade are being mainstreamed in the agro-food industry or whether they still have potential for an alternative organization of markets (Guthman 2004; Lockie and Halpin, 2005; Barrientos and Dolan, 2006; Lyon, 2007; Goodman et al. 2010).

The third direction, developed by Thévenot (1995) and Boltanski and Chiapello (1999) is engaged in examining how, in different historical periods, different combinations of 
conventions are predominant. Drawing from Weber's original concept of 'the spirit of capitalism', which includes the rationalization of the position of labour in capitalist society and the acceptability of extraction of value from the exploited, Boltanski and Chiapello (1999) argue that the evolution of capitalism over the last century or so can be understood through the emergence of different, albeit overlapping, 'value systems'. In this perspective, the end of the $19^{\text {th }}$ century was characterized by the so-called 'first spirit of capitalism', which was something akin to a 'domestic world' based on the entrepreneurial bourgeois. The 'second spirit of capitalism', which is seen to have lasted from the 1940s to the 1970s, was based on an 'industrial' and meritocratic logic, economies of scale (productivity), and the ideal of a large and integrated firm focusing on capturing market share. The 'third spirit', said to have emerged in the 1980s, is seen as being based on a 'network' logic and a new type of 'ideal firm' (flexible, organized by projects, lean). Under this 'spirit', competitive firms are smaller, innovative, and generally better able to plug into several different networks (see further critical engagements in Du Gay and Morgan, 2013).

Developing these arguments, but in more specific relation to conventions as instruments of facilitating coordination, Thévenot (1995), argues that the dominant form of economic organization in the post-war era was the result of a compromise between industrial and market conventions - with a tendential predominance of industrial notions of productivity, economies of scale and technical progress. He argues that this configuration later on tilted to the side of market coordination and its underlying concept of competitiveness - as a result of the processes of market liberalization and deregulation in the 1980s. Thévenot also claims that, at the same time, market conventions increasingly co-exists with domestic conventions based on geographic origin and branding - as well as with the underlying 'civic' content of environmental and socio-economic standards and labels. Furthermore, industrial norms are seen as being increasingly applied to the management of quality control.

In the next section, I review the Anglophone literature in agro-food studies that has explicitly drawn from CT. A proper engagement with how it may have indirectly influenced other streams of the agro-food literature more generally is outside of the scope of this review. However, in the conclusion, I will highlight a series of unique contributions that CT brings to the understanding of organization, coordination and exchange in the agro-food sector and how these provide intellectual stimuli and perhaps some challenges to other fields of agro-food studies.

\section{Convention theory in the Anglophone agro-food literature}

\subsection{Broad observations}

In this section, I briefly summarize the results of a literature review covering 51 articles, books and book chapters (see Table 2) that explicitly engage with convention theory either in terms of theoretical debate or review (13 entries), or as applied empirically in agro-food studies to understand specific sectors, regions, and case studies (38 entries).

\section{TABLE 2 HERE}

Empirically, CT has been sometimes applied to explain global trends in specific sectors, certifications and commodities (6), but mostly to individual and comparative case studies in Europe, North America and Oceania (with some focusing on products sourced in the Global South) (24) - with Europe representing a large majority. Studies focusing on developing countries and emerging economies still represent a minority, despite the importance of agrofood industries there, with Africa (5) and Latin America (3) attracting some attention. 
While a wide array of sectors and products has been covered in this literature, from niche and local/regional foods to global commodities, the wine industry has been the most popular (10) - followed by coffee (4) and cut flowers, fresh fruit and vegetables (4). Organic, fair trade and other sustainability certifications (8) and geographic indications (6) have also attracted substantial empirical attention.

Thematically, the earliest-appearing (starting in 1999) and most popular area of application of CT has been in relation to discussions on the 'quality turn' in agro-food studies, and more specifically in debates on the emergence of so-called 'alternative agro-food networks' (AAFNs) (23 entries). A further two main thematic areas have used CT to examine: coordination and governance of agro-food value chains (10) and innovation and institutional change (7). In these thematic categories, the number of contributions using an explicit CT framing seem to have decreased in the early 2010s, with the exception of Raynolds (2012a; 2012b), Diaz-Bone (2013) and Ponte and Sturgeon (2014). At the same time, new thematic areas using CT have started to appear in the past few years, dealing with: environmental and land management (3); consumption and household food provisioning (3); and farm labour management (2).

The literature reviewed emerges from three main geographical locations where contributors are institutionally affiliated: the US (17 entries), Nordic countries (14), and the UK (11) with other contributors based in Spain (4), Italy (1), New Zealand (3), Portugal (1), Germany (1), Brazil (1), and Mexico (1). Clear clusters of contributions arise from groups that operate(d) at Cardiff University, the Danish Institute for International Studies, and Colorado State University. The institutional affiliation of contributors to this literature (at the time of publication) shows a large majority coming from geography, planning and environmental studies (20) and other multi-disciplinary environments (15), followed by sociology (14).

This literature reviewed here has appeared mostly in journal articles (45), but also in books (3) and book chapters (3), with the great majority of articles published in multi-disciplinary journals. The three main journals where this literature has appeared are the Journal of Rural Studies (9), Sociologia Ruralis (6), and Economy \& Society (4), with the most recent articles published on CT appearing in 2012. Other journals publishing more than one article have been Agriculture and Human Values (2), GeoForum (2), Journal of Agrarian Change (2), and Regional Studies (2).

Analytically, the literature has developed along two distinct (but sometimes overlapping) approaches: a first that engages with a agro-food adaption of the 'worlds of production' framework (Salais and Storper, 1992; Storper and Salais, 1997); and a second that applies the 'orders of worth' approach of Boltanski and Thevenot (1991[2006]) and further elaborations of 'quality conventions' (Eymard-Duvernay, 1989; Sylvander, 1995; Thévenot, 1995). I take these two in turn in the next two sub-sections, followed by a discussion of some recent innovations and developments in the CT literature.

\section{2 'Worlds of food' approaches}

In agro-food studies, the 'worlds of production' approach has been adapted to the special features of the sector and translated into 'worlds of food' (Morgan et al., 2006; see also Murdoch and Miele, 1999; Murdoch et al., 2000) characterized by distinctive local/regional cultural, ecological and political/institutional logics: (1) a world of mass industrial food production, where standardized technologies are applied to produce large volumes of generic foods sold to mass markets; (2) a world of niche production, where standardized technologies are used to produce high-quality and differentiated products for niche market; (3) a world of local production, where artisanal/traditional techniques are used to produce specialist foods sold to clients through close relationships; and (4) a world of high technology production, 
where specialized processes are used to deliver new, special or functional foods to mass markets (Sanchez-Hernandez et al. 2010: 470). Morgan et al. (2006) delineate these worlds of production in part on the basis of their relative emphasis of domestic, market and industrial conventions, arguing that producers in Southern European countries rely on domestic justifications and location of production more than in Northern European countries, where emphasis is on health and safety aspects, and related industrial justifications (see also Parrott et al., 2002).

The 'worlds of food' approach has been used in the agro-food literature to explain the strategic positioning of individual firms and their movements between worlds (Murdoch and Miele, 1999, 2004), with others (e.g. Trabalzi, 2007) highlighting how different worlds of production coexist even within individual firms. But more common has been a tendency to highlight collective approaches that strategically position specific clusters, localities and regions through trajectories of learning, innovation, clustering, and institutional change (Cidell and Alberts, 2006; Guthey, 2008; Lindkvist and Sanchez, 2008; Sanchez-Hernandez et al., 2010; Sanchez-Hernandez, 2011), or to specify the innovation systems and regulatory interventions that allow individual firms to move between worlds (Stræte, 2004; Barbera and Audifredi, 2012). For example, Cidell and Alberts (2006) examine quality conventions in the chocolate industry, and in particular the negotiations of quality that are related to the location of chocolate manufacturing, rather than where cocoa is grown. They highlight that agro-food quality can be linked to the geographies of manufacturing and innovation, in particular where these innovations were first introduced. Guthey (2008), in his analysis of the wine industry in Northern California, argues that changes in production practices, quality and performance can originate from local collective social processes, including the shaping of conventions. Guthey charts the characteristics of the two main paths to become a winemaker in Northern California: the 'practised winemaker' and the 'seasoned vineyard manager', both of which rely on regional relationships and networks that make their districts unique and a source of innovation. He concludes that practice and local specificity are as important as 'nature' and global forces in the making of quality.

Similarly, Sanchez-Hernandez and colleagues (Lindvkist and Sanchez, 2008; SanchezHernandez et al., 2010; Sanchez-Hernandez, 2011) through the study of wine innovation pathways in Castilla y Leon (Spain) (also in comparison to the salt fish industry in Norway), show that innovation can arise from explicit attempts by value chain players to 'adapt their conventions and to attach new qualities to their core product ... [and] improve their market performance' (Sanchez-Hernandez, 2011: 105; see also Stræte, 2004), but also point out that this can only happen if the whole value chain undertakes this rearrangement of conventions. Challenging established Southern Europe - Northern Europe binomial characterization of dominant conventions, Lindkvist and Sanchez (2008) actually show that wine producers adapted their production systems to new market demands in Spain, while salt fish producers in Norway continued with their traditional conventions and lacked innovation. This possible counter-trend is strengthened by the case study of wine in Piedmont (Italy), where the 'methanol scandal' of the mid-1980s triggered a change in quality conventions as coordination mechanisms that led to a major and successful change in the institutional configuration of wine production in the region (Barbera and Audifredi, 2012). Collectively, these authors argue that innovation can be embedded in the passage from one world of production to another through changing quality conventions, a process which can be facilitated by appropriate organizational structures in local production systems. These contributions highlight how CT has not only been used as heuristic device to characterize relations, coordination mechanisms and organizational features, but also as tool to inform firm-level strategy, possible regional or sectoral innovation interventions and regulation. 
A popular application of CT in the Anglophone agro-food literature has been in attributing one or another type of convention to the disclosure of quality to facilitate coordination efforts. Much discussion has been focused on examining the content of civic/ecological and domestic conventions, and whether these are being folded within a compromise of market and industrial conventions that allows 'alternative' quality traits to be mainstreamed and standardized (Andersen, 2011; Barham, 2002, 2003; Freidberg, 2003, 2004; Kirwan, 2006; Murdoch et al., 2000; Raynolds, 2002, 2004, 2012a, 2012b; Raynolds et al., 2007; Renard, 2003; Rosin, 2007). These contributions are themselves nested in the broader debates on the role and limitations of alternative food networks (Goodman et al. 2014), the role of standards, labels and certifications in actually delivering social and environmental change (Henson and Reardon, 2005; Gibbon et al., 2010; Henson and Humphrey, 2010), the possible 'mainstreaming' (or 'conventionalisation') of organic and fair trade movements (Guthman 2004; Goodman et al. 2010), and more general discussions on the changing role of ethics and corporate responsibility considerations in the structure and operation of agro-food production and trade, and in patterns of consumption (Barrientos and Dolan, 2006; Goodman and Sage, 2014).

CT contributions to the 'quality turn' and AAFN literatures have often relied on case studies based in industrialized countries (and especially in Europe), or on studies of North-South trade but with particular attention to the changing features of consumption in the global North. These broader literatures argue that many consumers have turned away from industrial agro-food products and towards 'high quality' products, including those characterized by organic or low external input practices, specific locations or regions, and those supplied through farmers' markets, short/local food supply chains, and agro-tourism or other kinds of multifunctional agricultural enterprises. This 'quality turn' is explained in part by consumers' heightened reflexivity (both in relation to 'intrinsic' quality and to production and process methods) and in part by reactions to repeated food scares in the 1990s (BSE, e-coli, salmonella). The combined result is seen as having led to the increasing importance of 'transparency' in agro-food networks - embedded in practices of quality assurance, traceability, geographic origin, sustainable agro-ecological practices and direct marketing schemes (Goodman, 2004).

In CT contributions, these trends have been framed as part of a general movement from industrial conventions (and the logic of mass production) to domestic conventions based on trust, tradition and place (Murdoch et al. 2000; Murdoch and Miele, 1999, 2006). Murdoch et al. (2000) in particular argue that quality is coming to be seen as inherent in more 'local' and 'natural' foods, thus that 'quality food production systems are being reembedded in local ecologies' (Ibid.: 103). Although they recognize that 'alternative conventions' are not sufficient to fundamentally transform the global food system, they suggest that 'domestic and ecological criteria can be used by local producers to secure their own positions in the networks on favorable terms' (Ibid.: 119).

But work with more explicit North-South framings has been more critical of the potential of civic and domestic conventions to transform agro-food systems. For example, Freidberg (2003; see also Freidberg, 2004) is critical of both inter-personal trust as the basis of 'quality', and of the ability of AAFNs to promote meaningful socio-economic change in developing countries. In her historical and comparative analysis of conventions in Anglophone (Zambia to the UK) and Francophone (Burkina Faso to France) horticultural trade, she finds that 'relationships based on trust ... are often just situations where one or all parties has no choice but to hope for luck or mercy ... Economies of quality . . . are not necessarily less exploitative than others' (2003: 98). She also notes that, in North-South trade, 'situations of 
exchange' are such that actors do not necessarily share ethical or behavioural norms. Rather, producers comply with retailers' demands because they have no choice (see also Busch and Tanaka, 1996), even though ecological and socio-cultural conditions of production are different from the ones predominant in the country of consumption.

Likewise, Raynolds (2002, 2004, 2012a, 2012b; Raynolds et al. 2007), in her work on organics, fair trade and other sustainability certification systems, has used CT to understand how quality contestations arise and are resolved in global commodity networks, and how 'contestations over divergent qualifications and how collective enrolment in particular conventions permits forms of control at a distance' (Raynolds, 2002: 409). In particular, she sees fair trade as enacting a 'mode of ordering of connectivity', where discursive and material relations are based on renewed investment in 'trust' (domestic convention). Furthermore, she points out that fair trade refers to civic norms and qualifications that are based on collective responsibility for (and evaluation of) societal benefits - thus extending domestic conventions to socially and spatially distant peoples and spaces. At the same time, she shows that fair trade is rooted in important ways in market conventions as it deals with mainstream distributors and retailers, and in industrial conventions rooted in formal standards, inspections and certifications (on similar lines, see Renard, 2003). And she recognizes that 'certifiers may align with profit-driven corporations in reasserting industrial standards and commercial price competition, with Fair Trade principles converted into auditable attributes and certification practices enabling new forms of control at a distance' (Raynolds, 2012b: 286). Along with much of the agro-food literature on this subject, Raynolds sees the dangers of 'mainstreaming' in alternative food networks. Yet, she argues that fair trade and organic certifications are better able to deliver progressive social change than voluntary initiatives that are based on industrial-type certifications. In other words, it is not the consideration of 'ethics' itself in agro-food production and trade that challenges establish power structured, but how ethics content is embedded in, and leveraged through, different conventions - with market-industrial elements more prone to hamper possible venues for progressive change.

\section{Convention theory and global value chain governance}

One of the direct influences of CT in the agro-food literature has been the application of a quality convention framework to explain the dominance of certain forms of coordination or organization, and specific dynamics of governance in global value chains (Ponte and Gibbon, 2005; Tallontire, 2007; Ponte, 2009; Coq-Huelva et al., 2011; Sanchez-Hernandez, 2011; Ponte and Sturgeon, 2014). Gibbon et al. (2008) place the use of CT in examining global value chain governance under the rubric of 'governance as normalizing', a unique approach in a literature otherwise occupied with either examining value distributions and exclusion mechanisms through more traditional political economy lenses, or with explaining different forms of coordination through transaction costs theory (Gereffi et al. 2005). As Gibbon et al. (2008) argue, the term 'normalizing' in this context does not mean 'making things normal', but re-aligning a given practice to be compatible with a standard or norm (see also Thévenot, 1997, 2015a). This literature examines how different orders of worth and related organizational principles can lead to different foci of justification once they are challenged; how these challenges are based on different sets of testing questions and measures of product quality; and how they have different transmission potential along value chains (Gibbon and Ponte, 2005; Daviron and Ponte, 2005; Ponte, 2009; Ponte and Daviron, 2011; see bottom line in Table 1). This literature shows that while quality conventions typically overlap, one or a specific combination (for example, market and industrial, or domestic and fame) often form a dominant underpinning for linkages in a value chain node at a particular time. Furthermore, it examines how dominant conventions may 'travel' along a chain, explains the factors that makes them travel, and identifies what actors have the normative power to impose one convention over another beyond a single node in the value chain node. 
Furthermore, Ponte and Sturgeon (2014) examine the possible role of different quality conventions in facilitating specific kinds of linkages at individual nodes of the value chain (market, modular, relational, captive and hierarchical; as in Gereffi et al., 2005). They argue that market linkages are facilitated by market conventions in simple transactions where the association of product quality with price is straightforward. Modular linkages are typically enabled by industrial conventions and the standards that underlie them, while spatiallyembedded domestic conventions go hand in hand with relational linkages and long-term, trust-based inter-firm relationships. Yet, they caution that these associations are loose and not deterministic, given that: different kinds of conventions can co-exist in each of the value chain nodes; firms can apply different conventions with different suppliers seeking exchange at the same value chain node; and different quality conventions can be applied simultaneously with the same supplier when negotiating product portfolios or long term contracts. Also, they show that three other quality conventions (civic, inspirational and fame) cannot be linked unequivocally to a specific form of value chain linkage.

In an empirical application of this approach, Ponte (2009) examined quality conventions in the wine value chain between South Africa and the UK, showing how certain instruments of verification that 'test' specific quality conventions translate into supply relations and divisions of labour that are employed to govern value chains in particular ways. Such instruments of verification make 'visible' and 'translate' the complex and hidden negotiations, interactions and representations that lay behind the crystallization of a convention (or the overlap of conventions) at a particular time and position in the value chain. He argues that the moment of testing is important as it is at that point that 'justifications' are rendered explicit, where socio-technical devices are 'pulled in', and different kinds of knowledges and expertise recruited. Finally, he shows how wine value chain operators may apply different conventions with different clients at the same time.

In another case study, Coq-Huelva et al. (2011) analyze the olive oil commodity chain in Andalusia, Spain by considering quality conventions as the basic elements in the 'daily working' of the commodity chain. They identify the main quality conventions characterizing selected nodes of the value chain and focus especially on industrial and market conventions, with some residual discussion on domestic conventions. In particular, they highlight that only in 'short' value chains farmers were successful in shaping their preferred (industrial) convention along the value chain.

More recently, CT has also been employed to analyze labour management systems in largescale farming in Africa (Gibbon and Riisgaard, 2014; Riisgaard and Gibbon, 2014). While the previous agro-food literature on this topic (from different analytical perspectives) had argued that farm labour management in Africa had undergone a transition from a 'domestic' to a 'market' system in the 1980s and early 1990s, Gibbon and Riisgaard (2014) argue that the present configuration can be explained as a combination of industrial and civic conventions. They use CT to critically interrogate established views on organizational dynamics in labourintensive farming of cut flowers in Kenya and extend their argument to high-value crops in Africa more generally. In constructive dialogue with political economy, Gibbon and Riisgaard (2014: 100) use convention theory 'as a tool for better discriminating the implicit constraints and opportunities (for labour) embodied in different labour management systems'. They find that industrial and civic conventions are dominant and that market and domestic approaches are present but residual. In a related contribution, Riisgaard and Gibbon (2014) call to 'go beyond the traditional convention theory tradition of describing how conventions manifest themselves to asking why certain conventions prevail in a specific context at a specific point in time' (Ibid.: 261). They examine the conditions under which certain conventions and specific combinations can emerge and become dominant in relation to labour management in cut flower farms in Kenya. They find that while compromises between market and industrial conventions are necessary to operate a business, compromises involving civic conventions 
can only materialize as a result of political imperatives caused by popular struggles. Their case study suggests that the stabilization of an industrial convention may be a necessary precondition for civic elements to emerge, and that adequate and continuous political pressure needs to accompany this process.

By employing meso- and micro- tools, these attempts of combining CT and political economy provide fine-tuned perspectives on structural inequality and value distributions, thus complementing the systemic and macro perspectives of the food regimes and commodity system literatures.

\section{New directions}

Fairly recent 'orders of worth' applications of convention theory in agro-food studies have provided new analytical developments in relation to three aspects: (1) new categories of conventions; (2) a plurality of moral orders; and (3) the role of compromises as temporal solutions.

In relation to new categories of conventions, of particular interest is Kirwan's (2006) analysis of how producers and consumers coordinate their mutual expectations on quality at farmers' markets, so that they differentiate the products on sale from the uniformity of mass-produced food. Kirwan develops the concept of a 'regard convention', one encompassing quality attributes that are not included within commodity exchange, and that, like domestic conventions, are built especially around personal interaction. The search by consumers of a more direct connection with the food they purchase is a key aspect here, including direct interaction with the actual producer to answer any consumer questions. Kirwan posits that the exchange of regard is inevitable where there is face-to-face interaction between producers and consumers, and is an important source of mutual satisfaction (Ibid: 308). Thus, proximity, trust, reciprocity and social connection play an important role in a 'regard convention', which is a combination of traits that is usually attached to domestic conventions (building of trust over time, tradition, locality and personal ties) and civic conventions (collective welfare of society), with elements of fame and green conventions (Ibid.: 310). In ways that somewhat recall Thévenot's (2006) regime of familiarity, which includes aspects of intimacy and care, Kirwan concludes that 'the overall atmosphere of the market is clearly an important contributor to the potential for regard through imparting a sense of conviviality, social intercourse and perhaps even mutual endeavour between the producers and consumers (Ibid.: 309).

A different analytical direction has concerned the application of orders of worth to outline different 'regimes of information'. Ekbia and Evans (2009) have applied this approach to explain decision-making related to environmental resources in the Midwest United States. They examine 'the situated practices of daily life involved in the creation and enactment of information' and delineate five worlds: an industrial world that sees information as measurement data; a market world that treats information as commodity; a civic world that uses information as documentation; a world of fame that mobilizes information as message; a domestic world, where information is used as anecdote; and an inspired world, where information is intuition. They show how two distinct owners of land with similar characteristics might actually put it into different uses because they draw from different regimes of information, even though they may have similar interests and draw from the same social networks. At the same time, two owners with land of differing characteristics might actually make identical land use decisions (Ibid.: 328).

A second new direction emerging in the literature arises from an increasing dissatisfaction with allocating empirical phenomena into one or another convention, moral order or stabilized compromise. This has led to efforts to examine how multiple justifications are used by actors 
simultaneously, as opposed to selective engagement in a single world (see, i.a., Busch, 2000; Rosin, 2008; Truninger, 2011). This is not new theoretically, as Boltanski and Thévenot (1991[2006]) had already argued that actors engage in different justifications depending on the situation. However, what is new is the empirical application of this aspect, which was rarely taken into consideration in previous literature. Murdoch and Miele (2004), for example, compare the justifications employed by a fast-food firm and the slow-food movement to show how each employs different justifications to tailor their strategic approaches to different audiences. Ponte (2009) shows how the same wine value chain operators apply different quality conventions depending on their targeted end-markets, activating a portfolio of parallel conventions rather than a stabilized compromise (similarly, see Trabalzi, 2007 on buffalo mozzarella). Rosin and Campbell (2009) identify farmers' criteria for choosing among different organic certification organizations and argue that CT should be used beyond 'the inherent dualisms of conventionalisation (real organic/capitalist organic) and bifurcation (social movement/industry or local/export)' (Ibid.: 38). Andersen (2011) highlights how consumers draw on plural moral orders in deciding whether to consume organic food or not, arguing that these choices are made not only in relation to civic conventions, but also to other justifications at the same time. And Truninger (2011) shows how demonstrations organized for the marketing of Bimby food processors mobilize multiple justifications to show its 'worth' for cooking. Similarly to others who have used the figure of 'compromise', these contributions show how different moral orders may be called upon in different situations of food provisioning, and how different sets of conventions are employed in uncertain and contested ways.

A third new direction is one examining the role of temporal settlements, rather than stable compromises, among different conventions. Nyberg and Wright (2013: 405), show how 'organizational actors employ compromise to temporally settle disputes between competing claims about environmental activities'. They examine compromises between two orders of worth. These compromises are temporary agreements that do not seek to clarify arguments seeking an agreement over one world. Rather, following Stark (2011), they argue that compromise can help in exploiting the overlap between worlds, for example making a product or service 'compatible to plural worlds by ensuring that is satisfies the tests in for example both the market and the green world ... such as, 'green' cars or carbon offsets (Nyberg and Wright, 2013: 409). In their analysis of how corporate environmental responsibility is enacted in a range of industries in Australia, they find that 'actors ultimately engaged in compromises between the articulated common goods in order to make sense of their own situation as well as comply with broader organizational requirements ... While criticism of corporate environmental activities could be resolved through the purification of reality tests and the removal of environmental claims, a more likely response was to engage in compromise. This involved developing new roles, products and services, to fit the social worlds of both the market and environment, i.e., making subjects, objects or concepts compatible to more than one world and responding to two different types of test' (Ibid.: 41113; see also Nyberg and Wright, 2012).

At the same time, Nyberg and Wright (2013) recognize that compromises are only temporary solutions that are subject to ongoing adaptation as a result of further criticism, leading to purification (removing a criticized product or activity) or to new compromises that can be perceived as more environmentally friendly (Ibid.: 416). They conclude that compromises, rather than stabilizing the market (Biggart and Beamish, 2003), facilitate 'the further domination of the market by validating the market mechanism and depoliticizing political activities' (Ibid.: 420). Incidentally, Nyberg and Wright's contribution seems to be the only application of CT in the Anglophone literature that explicitly employs the two categories of tests highlighted by Boltanski and Thevenot (1991[2006]): reality tests arising from internal criticism that question the fairness or accuracy of the situation in relation to a common good within a specific context; and clashes, or tests that question the validity or the relevance of the 
test itself and invoke an alternative world.

\section{Conclusion}

Convention theory has had an important influence in guiding various pockets of the Anglophone agro-food literature in the past two decades. This emerging literature has been produced mostly in multi-disciplinary environments, with strong roots in geography, environmental studies and sociology, and has distinctive foci in a relatively small number of institutions in the UK, US and the Nordic countries.

The implications of CT for various fields of agro-food studies have been far-reaching especially in relation to discussions of 'quality' and how it shapes organization, coordination and exchange. Specifically, CT suggests: first, that there is no 'universal' understanding of quality, as often assumed in many approaches rooted in agricultural and food economics; second, that quality is evaluated through social interaction in different ways depending on what convention (or combination of conventions) is used to justify evaluation and action, suggesting that the cognitive evaluation of quality is rooted in social interaction and the building common frames of reference, rather than (only) on structurally-determined power hierarchies as many political economy approaches would have it; third, that there is a direct link between understandings of quality and the social organization of production an exchange, thus suggesting a set of processual and situational factors shaping specific institutional features and trajectories; fourth, that different degrees of ease of transmission of conventions along value chains can be an important factor shaping their governance, adding a much subtler set of factors to the existing explanations of 'buyer power' in agro-food value chains; and fifth, that the same agro-food companies may draw on different quality conventions (or combinations) to tap into portfolios of different markets and market segments, thus disassembling the tendency to depict 'strategy' in unitary terms in business school approaches to agro-food studies.

The analysis of agro-food value chains through a CT perspective has steered attention away from a predominant preoccupation with transaction costs in discussions of value chain governance, and towards a pluralistic (and more sociological) understanding of 'quality' as a tool structuring production, exchange and consumption. As such, it projected CT as a possible tool for unpacking the more subtle dynamics of power characterizing relations between producers and buyers of agro-food products. This in turn both extended the palette of, and provided new interactions between, critical approaches in agro-food studies dealing with structured inequalities, distribution of value added, and the potential of alternative organizational systems. CT achieved this by: (1) providing a meso- and micro- approach to the understanding of inequality and value distributions, thus complementing the systemic and macro perspective of the food regimes and commodity system literatures; (2) offering a novel entry point into discussions of ethics as a 'quality trait' (as embedded in 'civic' conventions), thus contributing to the literatures on fair trade, organics and other sustainability movements (and certifications) and to what extent these offer alternatives rather than reinforcing existing inequalities (e.g. when civic conventions become embedded in market-industrial compromises); and (3) offering a structured but pluralistic way of unpacking 'quality', which can be used to understand the role and limitations of alternative organizational and network forms that are emerging under the 'quality turn', as highlighted in work on alternative food networks and the literature on agro-food standards.

At the same time, this review has highlighted some of the possible limitations in the applications of CT to agro-food studies. First, the CT literature has generally drawn explicitly from the 'worlds of production' approach of Salais and Storper (1992; Storper and Salais, 1997) and/or from some of the 'orders of worth' delineated by Boltanski and Thévenot, (1991[2006]) and related forms of coordination (Eymard-Duvernay, 1989; Thévenot, 1995) to 
examine market, industrial, domestic and civic conventions, with much fewer contributions drawing from fame and inspiration conventions. The two latter conventions have very distinctive traits, and merit consideration in further work - while they may be less prevalent than the other four, much of the literature has not explicitly attempted to assess whether this is the case empirically, and simply ignored them in their analytical framework. A qualitatively different issue is the relative lack of engagement with 'green/ecological' conventions (as in Thévenot et al., 2000; Blok, 2013). This, I argue, is less problematic - the case for a distinctive 'green/ecological' convention has been less convincing, given its extensive overlap with civic conventions; the same can be argued for a 'regard' convention (Kirwan, 2006) in relation to domestic conventions.

Second, much of the CT contributions speaking directly to the borader 'quality turn' and alternative food network literatures initially focused on changes in agro-food systems in Europe, examining the transformative potential of domestic and civic conventions in strengthening alternative agro-food networks. Characterizations of a Northern-Southern Europe divide based on the dominance of different kinds of conventions have now been replaced by more mixed, nuanced and plural 'geographies of worth'. One-dimensional trajectories of change between 'worlds of food' at the level of firm, cluster, geographic indication or industry have been enriched by examples of multiple and parallel dynamics. Also, more global CT applications have emerged, but are often focused on the transformative potential of fair trade. Still, while case studies in the Global South that go beyond fair trade are also emerging, a broader geographical diversity is still much needed in future research.

Third, there has been much interest in combining CT and political economy in view of permeating structural/macro analyses of agro-food industries and value chains with microand meso- dimensions of power. For example, in discussions of global value chain governance, efforts have been made to link different coordination mechanisms and different types of conventions at different nodes of the value chain, and to highlight how different conventions are differently suited to 'travel' along value chains and thus shape their governance. But empirical case studies of this kind are still few, and far more effort of this kind is needed both empirically and analytically.

Fourth, much attention has been paid in the agro-food CT literature to historical passages from one dominant convention to another, and to the stabilization of compromises between conventions. More recent work has started to explore the importance of unstable, multiple and parallel quality conventions which firms can draw from, depending on the end-market or exchange partner they interact with, and to temporary settlements among conventions. These are positive developments, but the methodological discussions of how different kinds of conventions are allocated to specific phenomena are often weak.

Fifth, most of the agro-food literature draws mainly from CT work that has been published in English, or that has been translated into English, missing out on other equally important Francophone contributions (e.g. Sylvander, 1995; Eymard-Duvernay, 1989; 2006a, 2006b; Thévenot, 2006). Furthermore, it applies CT to interpret social and economic phenomena and/or to contribute to other theoretical efforts (e.g. value chain governance), while empirical applications are rarely used to further develop CT as such. This is also a lost opportunity and may have to do with the intellectual trajectories of those who veered into using CT. Thus, future contributions highlighting these trajectories and the perceived inadequacies of the available theoretical lens would be most helpful.

A final reflection refers to the relative decline of CT publications focusing on agro-food production, alternative networks, value chain governance and producer-consumer relations from 2010 onwards. Does this represent a 'crisis' of CT in the agro-food literature? I argue that this is not the case. Despite the limitations highlighted above, CT should be seen as a 
corpus of work in constant development. A first positive sign is that there has been increasing interest in exploring new fields such as farm labour and environmental management. Second, a nascent literature is moving beyond justification to examine a plurality of 'regimes of engagement' (Thévenot, 2006). In this literature, justification is re-cast as one of a variety of possible kinds of engagement in action involving (e)valuation and testing moments. Although Thévenot's book on regimes of engagement has not yet been translated into English, several articles and book chapters in English are available (Thévenot, 2001, 2002b, 2007, 2009, 2011, 2013, 2014, 2015a) and an Anglophone agro-food literature is now starting to appear (see Cheyns, 2011, 2014; Ponte and Cheyns, 2013; Blok and Meilvang, 2014; Centemeri, 2015; Silva-Castañeda, 2012, 2015a, 2015b). In conclusion, CT research in agro-food has left an important imprint in agro-food studies, and is very much alive. Yet, it would benefit from a broader geography of case studies, comparative work, methodological discussions and refinements, and further efforts at theory building within CT itself.

\section{References}

Allaire, G., Boyer, R. 1995. La grande transformation de l'agriculture: Lectures conventionnalistes et regulationnistes. INRA-Economica, Paris.

Andersen, A.H. 2011. Organic food and the plural moralities of food provisioning. Journal of Rural Studies 27 (4), 440-450.

Barbera, F., Audifredi, S. 2012. In pursuit of quality: the institutional change of wine production market in Piedmont. Sociologia ruralis 52 (3), 311-331.

Barham, E. 2002. Towards a theory of values-based labeling. Agriculture and Human Values $19,349-360$.

Barham, E. 2003. Translating terroir: the global challenge of French AOC labeling. Journal of Rural Studies 19, 127-138.

Barrientos, S., Dolan, C. (Eds.) 2006. Ethical Sourcing and the Global Food System. Earthscan, London.

Barnett, C. 2014. Geography and ethics III: from moral geographies to geographies of worth. Progress in Human Geography 38 (1), 151-160.

Batifoulier, P. (Ed.) 2001. Théorie des conventions. Economica, Paris.

Biggart, N.W., Beamish, T.D. 2003. The economic sociology of conventions: habit, custom, practice, and routine in market order. Annual Review of Sociology 29, 443-464.

Blok, A. 2013. Pragmatic sociology as political ecology: on the many worths of nature(s). European Journal of Social Theory 16 (4), 492-510.

Blok, A., Meilvang, M.L. 2014. Picturing urban green attachments: civic activists moving between familiar and public engagements in the city. Sociology, http://soc.sagepub.com/content/early/2014/05/22/0038038514532038

Boltanski, L., Chiapello, E. 1999. Le nouvel esprit du capitalisme. Gallimard, Paris. [English translation (2005) The new spirit of capitalism. Verso, London].

Boltanski, L., Thévenot, L. 1991. De la justification: les économies de la grandeur. Gallimard, Paris. [English translation (2006) On justification: Economies of worth. Princeton University Press, Princeton].

Busch, L. 2000. The moral economy of grades and standards. Journal of Rural Studies 16, 273-283. 
Busch, L., Tanaka, K. 1996. Rites of passage: constructing quality in a commodity subsector. Science, Technology and Human Values 21 (1), 3-27.

Centemeri, L. 2015. Reframing problems of incommensurability in environmental conflicts through pragmatic sociology: from value pluralism to the plurality of modes of engagement with the environment. Environnemental Values 24 (3), 299-320.

Cheyns, E. 2011. Multi-stakeholder initiatives for sustainable agriculture: limits of the 'inclusiveness' paradigm, in S. Ponte, S., P. Gibbon and J. Vestergaard (Eds) Governing through standards: Origins, drivers and limitations. Palgrave Macmillan, Basingstoke.

Cheyns, E. 2014. Making "minority voices" heard in transnational roundtables: the role of local NGOs in reintroducing justice and attachments. Agriculture and Human Values 31 (3), 439-453.

Cidell, J.L., Alberts, H.C. 2006. Constructing quality: the multinational histories of chocolate. Geoforum 37 (6), 999-1007.

Coq-Huelva, D., García-Brenes, M.D., Sabuco-i-Cantó, A. 2012. Commodity chains, quality conventions and the transformation of agro-ecosystems: olive groves and olive oil production in two Andalusian case studies. European Urban and Regional Studies 19 (1), 77-91.

Daviron, B., Ponte, S. 2005. The coffee paradox: global markets, commodity trade and the elusive promise of development. Zed Books, London.

Diaz-Bone, R. 2013. Discourse conventions in the construction of wine qualities in the wine market. Economic Sociology 14 (2), 46-53.

Du Gay, P., Morgan, G. (Eds.) 2013. New spirits of capitalism? Crises, justifications, and dynamics. Oxford University Press, Oxford.

Ekbia, H.R., Evans, T.P. 2009. Regimes of information: land use, management, and policy. The Information Society 25 (5), 328-343.

Evans, D. 2011. Consuming conventions: sustainable consumption, ecological citizenship and the worlds of worth. Journal of Rural Studies 27 (2), 109-115.

Eymard-Duvernay, F. (Ed.) 2006a. L'économie des conventions, méthodes et résultats. Tome 1: Débats. La Découverte, Paris.

Eymard-Duvernay, F. (Ed.) 2006b. L'économie des conventions, méthodes et résultats. Tome 2: Développements. La Découverte, Paris.

Eymard-Duvernay, F. 1989. Conventions de qualité et formes de coordination. Revue Economique 40 (2), 329-359

Eymard-Duvernay, F., Thévenot, L. 1986. L'économiste et son modèle. In: Thévenot, L. (Ed.) Conventions économiques. Cee - Presses Universitaires de France, Paris, pp. 129-50.

Favereau, O., Lazega, E. (Eds.) 2002. Conventions and structures in economic organization. Edward Elgar, Cheltenham.

Freidberg, S. 2003. Culture, conventions and colonial constructs of rurality in South-North horticultural trades. Journal of Rural Studies 19, 97-109.

Freidberg, S. 2004. French beans and food scares: culture and commerce in an anxious age. Oxford University Press, New York.

Friedland, W.H. 1994. The global fresh fruit and vegetable system: an industrial organization analysis, in P. McMichael (Ed.), The Global Restructuring of Agro-food Systems. Cornell University Press, Ithaca. 
Friedmann, H. 1987. International regimes of food and agriculture since 1870, in T. Shanin (Ed). Peasants and Peasant Societies. Blackwell, Oxford.

Friedmann, H., McMichael, P. 1989. Agriculture and the state system: the rise and fall of national agricultures, 1870 to the present. Sociologia Ruralis 29 (2), 93-117.

Gereffi, G., Humphrey, J., Sturgeon, T. 2005. The governance of global value chains. Review of International Political Economy 12 (1), 78-104.

Gibbon, P., Bair, J., Ponte, S. 2008. Governing global value chains: an introduction. Economy and Society 37 (3), 315-338.

Gibbon, P., Ponte, S. 2005. Trading down: Africa, value chains and the global economy. Temple University Press, Philadelphia.

Gibbon, P., Ponte, S., Lazaro, E. (Eds) (2010). Global agro-food trade and standards. Palgrave Macmillan, Basingstoke.

Gibbon, P., Riisgaard, L. 2014. A new system of labour management in African large-scale agriculture? Journal of Agrarian Change 14 (1), 94-128.

Goodman, D. 2004. Rural Europe redux? Reflections on alternative agro - food networks and paradigm change. Sociologia ruralis 44 (1), 3-16.

Goodman, D., DuPuis, M, Goodman, M.K. (Eds) 2014. Alternative Food Networks: Knowledge, Practice and Politics. Routledge, London.

Goodman, D., Watts, M. (Eds.) 1997. Globalising Food: Agrarian Questions and Global Restructuring. Routledge, London.

Goodman, M.K., Sage, C. (Eds.) 2014. Food Transgressions: Making Sense of Contemporary Food Politics. Ashgate, Farnham.

Goodman, M.K., Maye, D., Holloway, L. 2010. Ethical foodscapes? Premises, promises, and possibilities. Environment and Planning A 42 (8), 1782.

Guthey, G.T., 2008. Agro-industrial conventions: some evidence from northern California's wine industry. The Geographical Journal 174, 138-148.

Guthman, J. 2004. The trouble with 'organic lite' in California: A rejoinder to the 'conventionalisation' debate. Sociologia Ruralis 44 (3), 301-316.

Gwynne, R.N. 2006. Governance and the wine commodity chain: upstream and downstream strategies in New Zealand and Chilean wine firms. Asia Pacific Viewpoint 47, 381395.

Henson, S., Humphrey, J. 2010. Understanding the complexities of private standards in global agri-food chains as they impact developing countries. Journal of Development Studies 46 (9), 1628-1646.

Henson, S., Reardon, T. 2005. Private agri-food standards: Implications for food policy and the agri-food system. Food Policy 30 (3), 241-253.

Kirwan, J., 2006. The interpersonal world of direct marketing: examining conventions of quality at UK farmers' markets. Journal of Rural Studies 22, 301-312.

Latour, B. 1998. 'To modernise or ecologise? That is the question', in B. Braun and N. Castree (Eds.) Remaking Reality: Nature at the Millennium. Routledge, London and New York.

Lindkvist, K.B., Sánchez, J.L. 2008. Conventions and innovation: a comparison of two localized natural resource-based industries. Regional Studies 42, 343-354. 
Lockie, S., Halpin D, 2005. The conventionalisation thesis reconsidered: Structural and ideological transformation of Australian organic agriculture. Sociologia Ruralis 45 (4), 284- 307.

Lyon, S., 2007. Maya coffee farmers and fair trade: Assessing the benefits and limitations of alternative markets. Culture and Agriculture 29 (2), 100-112.

Marsden, T., Banks, J., Bristow, G. 2000. Food supply chain approaches: exploring their role in rural development. Sociologia Ruralis 40, 424-438.

McMichael P. 1994. The Global Restructuring of Agro-food Systems. Cornell University Press, Ithaca.

Morgan, K., Marsden, T., Murdoch, J. 2006. Worlds of food: Place, power, and provenance in the food chain. Oxford University Press, Oxford.

Murdoch, J., Marsden, T., Banks, J. 2000. Quality, nature and embeddedness: some theoretical considerations in the context of the food sector. Economic Geography 76, $107-125$.

Murdoch, J., Miele, M. 1999. 'Back to nature': changing 'worlds of production' in the food sector. Sociologia Ruralis 39, 465-483.

Murdoch, J., Miele, M. 2004. Culinary networks and cultural connections: A conventions perspective. In: A. Hughes, Reimer, S. (Eds.), Geographies of commodity chains. Routledge, London, pp. 102-119.

Nyberg, D., Wright, C. 2013. Corporate corruption of the environment: sustainability as a process of compromise. The British journal of sociology 64 (3), 405-424.

Orléan, A. 2004. L'économie des conventions: définitions et résultats', preface to the $4^{\text {th }}$ edition of A. Orlean (ed.) Analyse économique des conventions. Presses Universitaires de France, Paris.

Parrott, N., Wilson, N., Murdoch, J. 2002. Spatializing quality: regional protection and the alternative geography of food. European Urban and Regional Studies 9, 241-261

Ponte, S. 2009. 'Governing through quality: conventions and supply relations in the value chain for South African wine. Sociologia Ruralis 49 (3), 236-257.

Ponte, S., Cheyns. E. 2013. Voluntary standards, expert knowledge and the governance of sustainability networks. Global Networks 13 (4), 459-477.

Ponte, S., Daviron, B. 2011. Creating and Controlling Symbolic Value. In: Bandelj, N., Wherry, F. (Eds.) The cultural wealth of nations. Stanford University Press, Stanford.

Ponte, S., Gibbon, P. 2005, Quality standards, conventions and the governance of global value chains. Economy and Society 34 (1), 1- 31.

Ponte, S., Sturgeon, T. 2014. Explaining governance in global value chains: a modular theorybuilding effort. Review of International Political Economy 21 (1), 195-223.

Pritchard, B. 1996. Shifts in food regimes, regulation and producer cooperatives: insights from the Australian and US dairy industries. Environment and Planning A 28 (5), $857-$ 75.

Raikes, P., Jensen, M.F., Ponte. S. 2000. Global commodity chain analysis and the French filiére approach: comparison and critique. Economy and Society 29 (3), 390-417.

Raynolds, L.T. 2002. Consumer/producer links in fair trade coffee networks', Sociologia Ruralis 42 (4), 404-424.

Raynolds, L.T. 2004. The globalization of organic agro-food networks. World Development $32(5), 725-743$. 
Raynolds, L.T. 2012a. Fair trade: social regulation in global food markets. Journal of Rural Studies 28 (3), 276-287.

Raynolds, L.T. 2012b. Fair trade flowers: global certification, environmental sustainability, and labor standards. Rural Sociology 77 (4), 493-519.

Raynolds, L.T., Murray, D., Heller, A. 2007. Regulating sustainability in the coffee sector: a comparative analysis of third-party environmental and social certification initiatives. Agriculture and Human Values 24 (2): 147-163.

Renard, M.C. 2003. Fair trade: quality, market and conventions. Journal of Rural Studies 19, 87-96.

Riisgaard, L., Gibbon, P. 2014. Labour management on contemporary Kenyan cut flower farms: foundations of an industrial-civic compromise. Journal of Agrarian Change 14 (2), 260-285.

Rosin, C. 2007. Justifying the 'alternative': renegotiating conventions in the yerba mate network. In: Maye, D., Holloway, L, Kneafsey, M. (Eds) Constructing 'alternative' food geographies: representation and practice, Elsevier, pp. 115-132.

Rosin, C. 2008. The conventions of agri-environmental practice in New Zealand: farmers, retail driven audit schemes and a new spirit of farming. GeoJournal 73, 45-54.

Rosin, C., Campbell, H. 2009. Beyond bifurcation: examining the conventions of organic agriculture in New Zealand. Journal of Rural Studies 25, 35-47.

Salais, R. 1989. L'analyse économique des conventions de travail. Revue Economique 40 (2), $199-240$.

Salais, R., Storper, M. 1992. The Four 'Worlds' of Contemporary Industry. Cambridge Journal of Economics 16, 169-193.

Salais, R., Thévenot, L. 1986. Le travail (marchés, règles, conventions). INSEE/Economica, Paris.

Sánchez-Hernández, J.L., Aparicio-Amador, J., Alonso-Santos, J.L. 2010. The shift between worlds of production as an innovative process in the wine industry in Castile and Leon (Spain). Geoforum 41 (3), 469-478.

Sánchez - Hernández, J.L. 2011. The food value chain as a locus for (dis) agreement: conventions and qualities in the Spanish wine and Norwegian salted cod industries. Geografiska Annaler: Series B, Human Geography 93 (2), 105-119.

Sassatelli, R. 2004. The political morality of food: discourses, contestation and alternative consumption. In: Harvey, M., McMeeckin, A., Warde, A. (Eds.) Qualities of food: alternative theoretical and empirical approaches, Manchester University Press, Manchester, pp. 176-91.

Silva-Castañeda, L. 2012. A forest of evidence: third-party certification and multiple forms of proof - a case study on oil palm plantations in Indonesia. Agriculture and Human Values 29, 361-371.

Silva-Castañeda, L. 2015a. In the shade of benchmarking metrics: normative and ontological issues in the governance of land. Environment and Planning A, forthcoming.

Silva-Castañeda, L. 2015b. What kind of space? Multi-stakeholders initiatives and the protection of land rights. International Journal of Sociology of Agriculture and Food, forthcoming.

Stark, D. 2011. The sense of dissonance: accounts of worth in economic life. Princeton University Press, Princeton. 
Storper, M., Salais, R. 1997. Worlds of production: the action frameworks of the economy. Harvard University Press, Cambridge, MA.

Stræte, E.P., 2004. Innovation and changing 'worlds of production': case-studies from Norwegian dairies. European Urban and Regional Studies 11, 227-241.

Tallontire, A. 2007. CSR and regulation: towards a framework for understanding private standards initiatives in the agri-food chain. Third World Quarterly 28 (4), 775-791.

Thévenot, L. 1983. L'économie du codage social. Critiques de l'économie politique 23-24, 188-222.

Thévenot, L. 1984. Rules and implements: investment in forms. Social Science Information 23 (1), 1-45.

Thévenot, L. 1995. Des marchés aux norms. In: Allaire, G., Boyer, R. (Eds.), La grande transformation de l'agriculture: lectures conventionnalistes et régulationnistes. INRAEconomica, Paris, pp.33-51.

Thévenot, L. 1997. Un gouvernement par les normes: pratiques et politiques des formats d'information. In ; Conein, B., Thévenot, L. (Eds.) Cognition et information en société. Ed. de l'EHESS (Raisons Pratiques 8), Paris, pp. 205-241.

Thévenot, L. 2001. Pragmatic regimes governing the engagement with the world. In: KnorrCetina, K., Schatzki, T., Savigny. E. (Eds.) The practice turn in contemporary theory. Routledge, London, pp. 56-73.

Thévenot, L. 2002a. Conventions of co-ordination and the framing of uncertainty. In: Fullbrook, E. (Ed.) Intersubjectivity in Economics. Routledge, London and New York.

Thévenot, L. 2002b. Which road to follow? The moral complexity of an 'equipped' humanity. In: Law, J., Mol, A. (Eds) Complexities: social studies of knowledge practices. Duke University Press, Durham and London, pp.53-87.

Thévenot, L. 2006. L'action au pluriel: sociologie des régimes d'engagement. Découverte, Paris.

Thévenot, L. 2007. The plurality of cognitive formats and engagements: moving between the familiar and the public. European Journal of Social Theory 10 (3), 413-427.

Thévenot, L. 2009. Governing life by standards: a view from engagements. Social Studies of Science 39 (5), pp.793-813.

Thévenot, L. 2011. Powers and oppressions viewed from the perspective of the sociology of engagements: a comparison with Bourdieu's and Dewey's critical approaches to practical activities. Irish Journal of Sociology 19 (1), 35-67.

Thévenot, L. 2013. The human being invested in social forms: four extensions of the notion of engagement. In: Archer, M., Maccarini A. (Ed.) Engaging with the world: agency, institutions, historical formations. Routledge, London and New York, pp.162-180.

Thévenot, L. 2014. Voicing concern and difference. from public spaces to common-places. European Journal of Cultural and Political Sociology 1 (1), 7-34.

Thévenot, L. 2015a. Certifying the world: power infrastructures and practices in economies of conventional forms. In: Aspers, P., Dodd, N. (Eds.) Re-Imagining Economic Sociology. Oxford University Press, Oxford, pp. 195-223, forthcoming.

Thévenot, L. 2015b. From codage social to economie des conventions: a thirty years perspective on the analysis of qualification and quantification investments. Historical Social Research, forthcoming.

Thévenot, L., Moody, M., Lafaye, C. 2000. Forms of valuing nature: arguments and modes of justification in French and American environmental disputes. In: Lamont, M., 
Thévenot, L. (Eds.) Rethinking comparative cultural sociology: repertoires of evaluation in France and the United States. Cambridge University Press, Cambridge.

Trabalzi, F. 2007. Crossing conventions in localized food networks: insights from southern Italy. Environment and Planning A 39, 283-300.

Valceschini, E., Nicholas, F. 1995. La dynamique économique de la qualité agro-alimentaire. In Nicholas, F., Valceschini, E. (Eds.) Agro-alimentaire: une économie de la qualité. INRA/Economica, Paris.

Wilkinson, J. 1997. A new paradigm for economic analysis. Economy and Society 26, 305-3. 
Table 1: Key features of 'worlds' and related quality conventions

\begin{tabular}{|c|c|c|c|c|c|c|}
\hline & \multicolumn{6}{|c|}{ Worlds and related quality conventions } \\
\hline & Inspired & Domestic & Fame & Civic & Market & Industrial \\
\hline Common principle & $\begin{array}{c}\text { Spiritual or creative } \\
\text { enhancement }\end{array}$ & Traditional benevolence & Renown in public opinion & Collective solidarity & Competition & Efficiency \\
\hline $\begin{array}{l}\text { Qualified objects and } \\
\text { processes }\end{array}$ & Innovation, creation & Specific assets & $\begin{array}{l}\text { Public relations, brand } \\
\text { names }\end{array}$ & $\begin{array}{c}\text { Negotiation, consultation, } \\
\text { distributional arrangements }\end{array}$ & Product units & $\begin{array}{c}\text { Plans, systems, controls, } \\
\text { forecasts }\end{array}$ \\
\hline $\begin{array}{l}\text { Questions underpinning the } \\
\text { test of 'quality' }\end{array}$ & $\begin{array}{l}\text { Is it new? Is it a } \\
\text { breakthrough? }\end{array}$ & $\begin{array}{l}\text { Does it follow tradition? } \\
\text { Can it be trusted? }\end{array}$ & $\begin{array}{l}\text { Is it accepted by the } \\
\text { public/consumers? }\end{array}$ & $\begin{array}{l}\text { What is the impact on } \\
\text { society? Is it safe, healthy, } \\
\text { environmentally sound? }\end{array}$ & Is it economic? & $\begin{array}{l}\text { Is it technically efficient, } \\
\text { scalable, functional? }\end{array}$ \\
\hline Measure of product quality & Personality, novelty & Trust, repetition, history & $\begin{array}{c}\text { Opinion polls, media and } \\
\text { social media coverage, } \\
\text { subjective judgement by } \\
\text { expert }\end{array}$ & $\begin{array}{c}\text { Social, labour, } \\
\text { environmental, collective } \\
\text { impact }\end{array}$ & Price & $\begin{array}{l}\text { Objective technical } \\
\text { measurement }\end{array}$ \\
\hline $\begin{array}{l}\text { Firms' organizational } \\
\text { principle }\end{array}$ & Creativity & Loyalty & Reputation & Responsibility & Competitiveness & Productivity \\
\hline $\begin{array}{l}\text { Ease of transmission along } \\
\text { value chains }\end{array}$ & Low & Low & Medium & Medium & High & High \\
\hline
\end{tabular}

Source: Adapted from Ponte (2009: 240), Ponte and Sturgeon (2014: 208) and Gibbon and Riisgaard (2014: 101). 
Table 2: Main features of literature included in the review

\begin{tabular}{|c|c|c|c|c|c|c|c|}
\hline Author(s) & $\begin{array}{l}\text { Publ } \\
\text { year }\end{array}$ & Journal/ Book & Geo & Discipline & Focus & Location of empirics & Thematic area \\
\hline Andersen & 2011 & Journal of Rural Studies & DK & Policy Studies & household food provisioning & Denmark & consumption/provisioning \\
\hline Barbera and Audifredi & 2012 & Sociologia Ruralis & IT & MD & wine, geo indications & Italy & innovation \& instit change \\
\hline Barham & 2002 & Agriculture \& Human Values & US & Sociology & theory/review & na & quality turn and AAFNs \\
\hline Barham & 2003 & Journal of Rural Studies & US & Sociology & wine, geo indications & France & quality turn and AAFNs \\
\hline Biggart and Beamish & 2003 & Annual Review of Sociology & US & Sociology & theory/review & na & general overview \\
\hline Blok & 2013 & European J of Social Theory & DK & Sociology & theory/review & na & env \& land management \\
\hline Busch & 2000 & Journal of Rural Studies & US & Sociology & theory/review & na & quality turn and AAFNs \\
\hline Cidell and Alberts & 2006 & GeoForum & US & GPE & chocolate & Europe & innovation \& instit change \\
\hline Coq-huelva et al. & 2012 & Regional Studies & SP & GPE & olive oil & Spain & GVCs \\
\hline Daviron and Ponte & 2005 & Book (Zed) & FR, DK & $\mathrm{MD}$ & coffee & Global, East Africa & GVCs \\
\hline Diaz-Bone & 2013 & Economic Sociology & GER & Sociology & wine & Germany & quality turn and AAFNs \\
\hline Ebkia and Evans & 2009 & Information Society & US & GRE, InfoSci & land management & US & env \& land management \\
\hline Evans & 2012 & Journal of Rural Studies & UK & Sociology & sustainable consumption & UK & consumption/provisioning \\
\hline Gibbon and Ponte & 2005 & Book (Temple) & DK & MD & coffee, clothing & Global, Africa & GVCs \\
\hline Gibbon and Riisgaard & 2014 & Journal of Agrarian Studies & DK & MD & cut flowers & Kenya & labour management \\
\hline Gibbon et al & 2008 & Economy \& Society & DK, US & $M D$ & theory/review & na & GVCs \\
\hline Goodman & 2004 & Sociologia Ruralis & US & GPE & theory/review & na & quality turn and AAFNs \\
\hline Guthey & 2008 & Geographical Journal & US & GPE & wine & US & innovation \& instit change \\
\hline Gwynne & 2006 & Asia Pacific Viewpoint & UK & GPE & wine & New Zealand, Chile & GVCs \\
\hline Kirwan & 2006 & Journal of Rural Studies & UK & $M D$ & farmers markets & England & quality turn and AAFNs \\
\hline Lindkvist and Sanchez & 2008 & Regional Studies & NO, SP & GPE & wine/geo ind and salt fish & Spain, Norway & innovation \& inst change \\
\hline Marsden et al & 2000 & Sociologia Ruralis & UK & GPE & theory/review & na & quality turn and AAFNs \\
\hline Morgan et al & 2006 & Book (Oxford) & UK & GPE & multiple cases & Italy, UK, US & quality turn and AAFNs \\
\hline Murdoch and Miele & 2004 & Book Ch (Routledge) & UK & GPE, ag econ & multiple cases & Italy & quality turn and AAFNs \\
\hline Murdoch and Miele & 1999 & Sociologia Ruralis & UK & GPE, ag econ & eggs and organic meat & Italy & quality turn and AAFNs \\
\hline Murdoch et al & 2000 & Economic Geography & UK & GPE & theory/review & na & quality turn and AAFNs \\
\hline
\end{tabular}




\begin{tabular}{|c|c|c|c|c|c|c|c|}
\hline Ponte & 2009 & Sociologia Ruralis & DK & MD & wine & South Africa & GVCs \\
\hline Ponte and Daviron & 2011 & Book Ch (Stanford) & DK & MD & wine & South Africa & GVCs \\
\hline Ponte and Gibbon & 2005 & Economy \& Society & DK & $\mathrm{MD}$ & theory/review & na & GVCs \\
\hline Ponte and Sturgeon & 2014 & Review of Int Pol Economy & DK, US & MD & theory/review & na & GVCs \\
\hline Raikes et al & 2000 & Economy \& Society & DK & $\mathrm{MD}$ & theory/review & na & general overview \\
\hline Raynolds & $2012 b$ & Journal of Rural Studies & US & Sociology & fair trade & Global & quality turn and AAFNs \\
\hline Raynolds & 2002 & Sociologia Ruralis & US & Sociology & fair trade, coffee & Global & quality turn and AAFNs \\
\hline Raynolds & 2004 & World Development & US & Sociology & organic & Global & quality turn and AAFNs \\
\hline Raynolds & $2012 a$ & Rural Sociology & US & Sociology & fair trade, cut flowers & Ecuador & quality turn and AAFNs \\
\hline Raynolds et al & 2007 & Agriculture \& Human Values & US & Sociology & sustainability certifications & Global & quality turn and AAFNs \\
\hline Renard & 2003 & Journal of Rural Studies & Mexico & Sociology & fair trade, coffee & Global, Mexico & quality turn and AAFNs \\
\hline Riisgaard and Gibbon & 2014 & Journal of Agrarian Studies & DK & MD & cut flowers & Kenya & labour management \\
\hline Rosin & 2007 & Book Ch (Elsevier) & $\mathrm{NZ}$ & GPE & yerba mate & Brazil & quality turn and AAFNs \\
\hline Rosin & 2008 & GeoJournal & $\mathrm{NZ}$ & GPE & kiwi, dairy & New Zealand & quality turn and AAFNs \\
\hline Rosin and Campbell & 2009 & Journal of Rural Studies & $\mathrm{NZ}$ & GPE & organic & New Zealand & quality turn and AAFNs \\
\hline Sanchez-Hernandez & 2011 & Geografiska Annaler B & SP & GPE & wine/geo ind and salt fish & Spain, Norway & innovation \& instit change \\
\hline Sanchez-Hernandez et al & 2010 & GeoForum & SP & GPE & wine, geo ind & Spain & innovation \& instit change \\
\hline Stræte & 2004 & Eur Urban and Reg Studies & NO & GPE & dairy & Norway & innovation \& instit change \\
\hline Tallontire & 2007 & Third World Quarterly & UK & MD & theory/review & na & GVCs \\
\hline Trabalzi & 2007 & Environment and Planning $\mathrm{A}$ & US & MD & dairy & Italy & quality turn and AAFNs \\
\hline Truninger & 2011 & Journal of Consumer Culture & POR & MD & a food processor & Portugal & consumption/provisioning \\
\hline Wilkinson & 1997 & Economy \& Society & BRA & Sociology & theory/review & na & general overview \\
\hline
\end{tabular}

Legend:

Geo: geography of authors' institutional affiliation at the time of writing; Discipline: disciplinary base of institutional affiliation of the authors at the time of publication

$\mathrm{MD}=$ multidisciplinary; GPE = geography, planning and environmental studies

GVCs = global value chains; AAFNs = alternative agro-food networks

$\mathrm{n} / \mathrm{a}=$ not applicable 